\title{
Pectotibialis paghmanensis Tshernyshev gen. nov. - a new genus and species of soft-winged flower beetle (Coleoptera, Cleroidea, Malachiidae) from Afghanistan
}

\author{
Sergei E. TSHERNYSHEV (1) 1,2 \\ ${ }^{1}$ Institute of Systematics and Ecology of Animals, Siberian Branch of the Russian Academy \\ of Sciences, Frunze Street 11, 630091 Novosibirsk, Russia. \\ ${ }^{2}$ Tomsk State University, Lenina prospekt 36, Tomsk 634050, Russia. \\ Email: sch-sch@mail.ru \\ urn:1sid:zoobank.org:author:C9CC4A86-BD1F-499A-B831-F727A111BBAA
}

\begin{abstract}
A new genus with a new species of soft-winged flower beetle, Pectotibialis paghmanensis Tshernyshev gen. et sp. nov. are described from Afghanistan. The new genus can be distinguished from the congeners of the tribe Apalochrini by the dark pectination in the apices of tibiae in both sexes, and the anterior tibiae which are hollowed at distal half, flattened and rounded femora, bituberculate basal parts of head and pronotum, two lamellate metathoracic appendages, tarsal comb above second tarsomere of anterior legs, and serrate antennae in the male. Based on the metathoracic appendages and comb in anterior legs would attribute this new species to the new genus Dromanthomorphus Pic, 1921, but all the other above-mentioned characters define its independent status and the designation of a new genus; Pectotibialis Tshernyshev gen. nov. The external appearance, special male characters and genitalia of the type species of the new genus are illustrated, and a distribution map is provided. A key to the Apalochrus-section of the tribe Apalochrini is provided.
\end{abstract}

Keywords. Afghanistan, soft-winged flower beetle, Apalochrini, Pectotibialis, new genus, new species, systematics.

Tshernyshev S.E. 2021. Pectotibialis paghmanensis - a new species and a new genus of soft winged flower beetle of the tribe Apalochrini (Coleoptera, Cleroidea, Malachiidae) from Afghanistan. European Journal of Taxonomy 775 : 1-14. https://doi.org/10.5852/ejt.2021.775.1539

\section{Introduction}

Amongst the soft-winged flower beetles obtained by my colleague Oleg Pak in Afghanistan were several specimens of narrow, parallel-sided malachiids resembling representatives of the genus Apalochrus Erichson, 1840 and belonging to the tribe Apalochrini. The male has with a comb above the second tarsomere in the anterior legs, and this character allows this species to be placed near Protapalochrus Evers, 1987. Both genera, Apalochrus Erichson and Protapalochrus Evers, are distributed in Central Asia, and two species, A. flavicollis Schaufuss, 1870 and P. (P.) fedtschenkoi (Solsky, 1882), are known from Afghanistan (Mayor 2003, 2007; Tshernyshev 2015c, 2016b); however, the newly found taxon 
differs from them by the monochromous dark colouration of its surface which lacks yellow-orange spots. Further study of the male has revealed characters previously unknown in any members of the tribe Apalochrini Mulsant \& Rey, 1867. The metathorax is swollen and impressed in the middle, with two lamellate appendages located below, near distal edge, and above, closer to mesothorax. The metathoracic appendages allow placing this species near Dromanthomorphus Pic, 1921, but species of this genus have only one appendage at the base of metathorax which is not lamellate and a different shape, and they also have swollen intermediate tibiae. These characters show that the species found in Afghanistan is different from Dromanthomorphus Pic. Another genus of the tribe with a thorn-like metathoracic appendage, Mimapalochrus Tshernyshev, 2015, occurs in SE Asia and is distinguishable by the elytral apices impressed near the suture, swollen anterior and an intermediate femora, simple not emarginate anterior tibiae slightly widened posteriorly, the presence of pheromone glands on intermediate tibiae, and extremely large eyes. Hence, the newly found species does not belong to any known genera of the tribe Apalochrini and represents a new genus and new species.

The tribe Apalochrini unites soft-winged flower beetles with typical antennae possessing a second antennomere which is extremely small, round or oval, usually almost completely hidden by the scape, so that the antennae appear to be 10-segmented. The highest species diversity of the tribe occurs in SE Asia, Africa and Australia where species have a wide spectrum of male characters of importance to differentiate taxa. The taxonomic structure of the tribe has been recently discussed with special reference to southern Asian genera, and, a number of recent articles devoted to, or pertaining to, the Malachiidae Fleming, 1821 fauna of the Himalayas and an area of south-east Asia and Australia have been published (Yoshitomi 2008, 2010, 2014; Asano \& Kojima 2009, 2013, 2014; Tshernyshev 2009, 2012b, 2015a-e, 2016a-d, 2018, 2020a-c; Asano \& Kawashima 2010; Yoshitomi \& Lee 2010; Asano \& Yoshitomi 2011; Asano et al. 2011 a, 2011b, 2018; Geiser 2011; Asano 2013a, 2013b, 2015, 2017 , 2018; Asano \& Okajima 2013; Plonski 2013, 2014a, 2014b, 2015, 2016, 2017; Plonski \& Geiser 2014; Plonski \& Michael 2014; Plonski \& Puchner 2014; Constantin 2015; Liu et al. 2015, 2016, 2017; Yoshitomi et al. 2015; Tshernyshev \& Kopetz 2018; Tshernyshev \& Shcherbakov 2020); however, further revision is still necessary to clarify our knowledge of the taxonomy.

Amongst those genera currently known in the tribe Aplochrini, four generic groups are considered, namely Apalochrus-group (Apalochrus Erichson, 1840, Paratinoides L. Medvedev, 1964, Protapalochrus Evers, 1987, Pectapalochrus Tshernyshev, 2016, Oculapalochrus Tshernyshev, 2015), Collops-group (Collops Erichson, 1840, Protocollops Evers, 1991, Troglocollops Wittmer, 1965, Simoderus Abeille de Perrin, 1891), Laius-group (Laius Guérin-Méneville, 1831, Intybia Pascoe, 1866, Troglointybia Tshernyshev, 2015, Dicranolaius Champion, 1921, Eulaius Wittmer, 1996), and Dromanthomorphusgroup (Dromanthomorphus Pic, 1921, Hadrocnemus Kraatz, 1895, Mimapalochrus Tshernyshev, 2015). Representatives of the four groups can be divided into two sections based on the modification of the basal antennomeres in the male. A key to the genera of the tribe Apalochrini with simple unmodified $1^{\text {st }}, 3^{\text {rd }}$ and/or $4^{\text {th }}$ antennomeres, the Apalochrus-section, is given below. The species from Afghanistan discussed above belongs to this section; the key to the other section is given in another article, currently awaiting publication.

However, the complex of male special characters for the new Afghanistan species necessitates a new genus, Pectotibialis Tshernyshev gen. nov., as described below, with Pectotibialis paghmanensis Tshernyshev sp. nov. selected as the type species.

\section{Material and methods}

For descriptions, special male structures and genitalia were studied; 'special male structures' refer to the sculptured head and pronotum, swollen, impressed and appendiculate metathorax, and excavate anterior tibiae. Illustrations for the species were prepared using specimens from the type locality: 
Pectotibialis paghmanensis Tshernyshev sp. nov. holotype, male and paratype, female - Afghanistan, Kabul Province, near Paghman village.

The specimens are currently deposited in the following institution, which is subsequently referred to by the acronym:

SCH_ISEA $\quad=\quad$ the author's collection, which is housed in the Institute of Animal Systematics and Ecology, Siberian Branch of the Russian Academy of Sciences, Novosibirsk, Russia.

The beetles were studied using an Amscope trinocular stereomicroscope (Ultimate Trinocular Zoom Microscope 6.7X-90X Model ZM-2TY), and digital photographs were taken using a Carl Zeiss Stemi 2000 trinocular microscope and the AxioVision programme. Male genitalia, embedded in DMHF (Dimethyl hydantoin formaldehyde), were mounted onto a transparent card and pinned under the specimen.

\title{
Results
}

\section{Taxonomy}

\author{
Class Insecta Linnaeus, 1758 \\ Order Coleoptera Linnaeus, 1758 \\ Suborder Polyphaga Emery, 1886 \\ Superfamily Cleroidea Latreille, 1802 \\ Family Malachiidae Fleming, 1821 \\ Subfamily Malachiinae Fleming, 1821 \\ Tribe Apalochrini Mulsant \& Rey, 1867 \\ Pectotibialis Tshernyshev gen. nov. \\ urn:Isid:zoobank.org:act:D03DBCE5-498E-4993-97EF-C0F6B741D9E4
}

\section{Type species}

Pectotibialis paghmanensis Tshernyshev sp. nov. fixed by monotypy in the present paper.

\section{Diagnosis}

Moderately small sized (ca 3.8-4.1 mm) soft-winged flower beetles with the body elongate, narrow, parallel-sided, slightly expanded posteriorly, with two or three apical ventrites of the abdomen not covered by elytra. Metallic green upperside with yellow or yellow-brown parts, i.e., labrum, labium, mandibles, palpi, mouthparts and antennae, tibiae and tarsi in all legs, coxae and trochanters of anterior legs and areas of joining between them in intermediate and posterior legs. Antennae weakly flabellate, not long, expanding over the base of elytra, with the $3^{\text {rd }}$ antennomere wide triangular. Head small, narrower than pronotum, interocular area slightly impressed and sculptured, frons tuberculate, eyes simple, not large, slightly protruding. Pronotum almost completely equilateral, narrowly transverse, impressed near basal margin, disk convex with wide subtriangular tubercle in the middle and looking bituberculate, basal side and basal half of lateral sides slightly flattened and distinctly marginate, and anterior side indistinctly marginate. Elytra parallel or slightly widened just below the middle, not covering two or three apical segments of the abdomen, coarsely punctured, with distinct and weakly protruding shoulders; apices evenly rounded, simple. Hind wings normally developed (in both sexes). Anterior tarsi with distinct transverse small comb above the $2^{\text {nd }}$ tarsomere and wide triangular $1^{\text {st }}$ tarsomere; claws very short and hidden by round transparent plates at base. Anterior tibiae strongly excavate dorsally in apical half with elongate tip looking like initial tarsomere, not swollen; intermediate and posterior tibiae simple, not 
swollen or emarginate, with the setae similar to that in tarsal comb arranged in apical edge near tarsus. Femora wide, roundly swollen, anterior with a dent in middle. Anterior trochanters oval and impressed to the basal half of the femur.

Metathorax swollen and impressed in the middle with two appendages, one lamellate transverse above, and the other longitudinal with a vertical round semi-transparent plate at apex. Pygidium elongate, equilateral, evenly rounded distally, ultimate abdominal ventrite bilaciniate, narrow, transverse, evenly narrowed dorsally and emarginate in the middle, aedeagus simple, weakly curved dorsally, narrow, with elongate narrow apical lamella, endophallus with a few denticles at apex of inner sac, tegmen long, narrow, with thin, short pointed parameres.

\section{Comparison}

Special male characters differentiating Pectotibialis Tshernyshev gen. nov. from all other members in the tribe Apalochrini are given in the key below. The new genus is similar to the genera Dromanthomorphus Pic and Oculapalochrus Tshernyshev in the presence of appendages on the metathorax and tarsal comb above the second tarsomere in the anterior legs of the male, but typical characters that differentiate it are as follows: distinguished from Dromanthomorphus Pic by simple, not widened intermediate tibiae and from Oculapalochrus Tshernyshev by simple eyes; the strongly excavate anterior tibiae in combination with the abbreviated elytra of the new genus are different from both genera.

\section{Notes}

This species and genus are known only from Afghanistan, Central Asia.

\section{List of species in the genus Pectotibialis:}

1. P. paghmanensis Tshernyshev gen. et sp. nov. (Afghanistan: Paghman).

Pectotibialis paghmanensis Tshernyshev sp. nov. urn:1sid:zoobank.org:act:93EC6FFD-B1D1-409F-B12A-081E1D5B96F5

Figs $1-2$

\section{Material examined}

\section{Holotype}

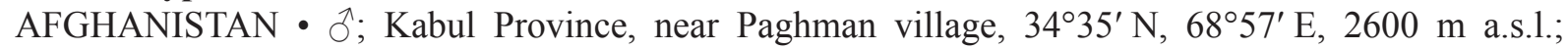
12 Jul. 2009; O. Pak leg.; SCH_ISEA_000123.

\section{Paratypes}

AFGHANISTAN • 6 \% ; same collection data as for holotype; SCH_ISEA_000124-129.

\section{Description}

\section{Holotype, male (Fig 1A-B)}

BoDy. Elongate, subparallel, slightly expanded posteriorly, elytra not covering two ultimate segments of the abdomen.

Labrum, Labium, mandibles, palpi, mouthPaRTS and antenNae. Yellow-brown, except for black spots on upper side of the $1^{\text {st }}$ antennomere (Fig. 2D), tibiae and tarsi in all legs, coxae and trochanters in anterior legs and commissure parts between them in intermediate and posterior legs and membranes of abdominal ventrites yellow, other body parts black-brown; upper surface of head, pronotum and elytra with a weak green metallic tint. Surface evenly covered with yellow-white dense fine long erect and curved hairs. Vesicles white-yellow, and thoracic mesepimera black. 


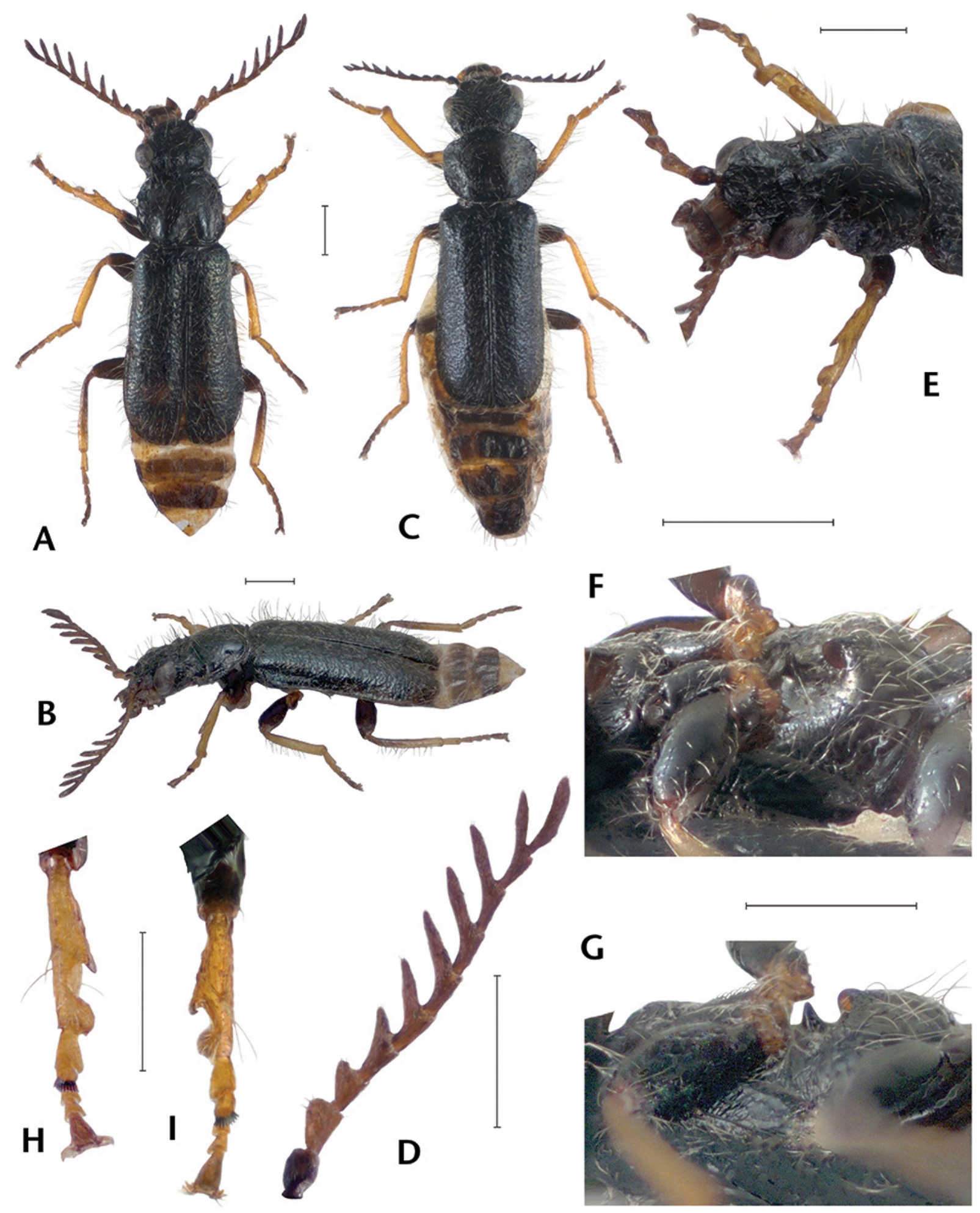

Fig. 1. Pectotibialis paghmanensis Tshernyshev gen. et sp. nov. A, B, D-I. Holotype, §ิ (SCH ISEA_000123). C. Allotype,, . A, C. External appearance, dorsal view. B. External appearance, lateral view. D. Right antenna. E. Head, pronotum and scutellum, subdorsal view. F. Metathorax, subdorsal view. G. Metathorax, lateral view. H. Left anterior tibia and tarsus, ventral view. I. Left anterior tibia and tarsus, dorsal view. Scale bars: $0.5 \mathrm{~mm}$. 
HEAD. Not wider than pronotum, interocular area slightly impressed and edged with thin carina, frons with two tubercles, eyes small, oval, weakly protruding; genae short and straight; clypeus narrow, transverse, straight; labrum narrow, transverse; palpae simple with apical segment slightly widened and securiform; surface of head dull, sparsely indistinctly punctured lacking microsculpture, evenly covered with light fine long and curved pubescence.

AntennAe. Weakly flabellate from $6^{\text {th }}$ to $11^{\text {th }}$ antennomeres (Fig. 1D), $1.7 \mathrm{~mm}$ long, reaching the base of elytra; $1^{\text {st }}$ antennomere enlarged, round-oval, $2^{\text {nd }}$ antennomere small, round, almost completely invisible, hidden by the $1^{\text {st }}$ antennomere, $3^{\text {rd }}$ and $4^{\text {th }}$ antennomeres triangular, the $3^{\text {rd }}$ is 1.2 times as long and wide as the $4^{\text {th }}$ antennomere, $5^{\text {th }}$ antennomere triangular with elongate outer edge and is as long as the $3^{\text {rd }}$ antennomere, but considerably narrower than it, $6^{\text {th }}$ to $10^{\text {th }}$ antennomeres with extended outer edges, apical segment elongate, thin, subcylindrical, slightly curved in basal third; surface evenly covered with short, yellowwhite adpressed pubescence with single erect longer light hairs on outer sides of the antennomeres.

Pronotum. Almost completely equilateral, narrowly transverse impressed near basal margin, disk convex with wide subtriangular tubercle in a middle and look bituberculate at base; anterior margin slightly convex; posterior margin straight; lateral sides almost completely straight with rounded angles; basal side and basal half of lateral sides slightly flattened and distinctly marginate, anterior side indistinctly marginate; surface glabrous, with sparse smoothed punctures lacking microsculpture, evenly covered with fine long curved light hairs.

SCUTELLUM. Small, triangular with rounded tip, almost completely covered by pronotum, sparsely punctured and covered with light semi-erect hairs.

ElYTRA. Oblong, parallel or slightly widened just behind the middle and evenly rounded distally, not covering three apical segments of the abdomen, at base not wider than pronotum; humeri small, slightly protruding; apices evenly rounded, simple; disc indistinctly marginate on external sides and along suture, lateral edge in middle near epipleura slightly impressed; surface dull, coarsely punctured and wrinkled, with smoothed microsculpture, evenly covered with yellow-white long erect hairs.

HIND WINGS. Normally developed.

LEGS. Not long; posterior femora not reaching elytral apices; anterior tibiae not swollen but widened distally and with a strong rectangular excavation inwardly in apical half so that the tip of the tibiae looks like a $1^{\text {st }}$ tarsomere (Fig. 1H-I), intermediate and posterior tibiae simple, not swollen or emarginate, with the setae similar to that in tarsal comb arranged in apical edge near tarsus, femora wide, roundly swollen, anterior with tooth in middle (Fig. 2A-B), anterior trochanter oval and impressed to the basal half of the femur, all tarsi 5 -segmented, slightly compressed and elongate, $2^{\text {nd }}$ tarsomere in anterior tarsi with small transverse comb above, the $1^{\text {st }}$ tarsomere enlarged, triangular, 1.3 times as long as the $2^{\text {nd }}$ tarsomere, 2 times as long as the $3^{\text {rd }}$ tarsomere and 3 times as long as the $4^{\text {th }}$ tarsomere, claw-segment flattened, as long as the $1^{\text {st }}$ tarsomere, claws very short and thin, almost completely hidden by round semi-transparent membrane at base. Surface of legs covered with light short semi-erect pubescence and sparse white long erect hairs.

Ventral BODy suRface. Sparsely punctured, shining, evenly and sparsely covered with long, fine, semierect white hairs; metathorax swollen and complicatedly sculptured: impressed in a middle, and with two protuberances, one lamellate transverse above, and the other longitudinal and possessing vertical round semi-transparent plate at apex (Fig. 1F-G). Pygidium slightly elongate, almost equilateral, evenly rounded distally, with long dark erect hair on outer side (Fig. 2C), ultimate abdominal ventrite is bilaciniate, narrow, transverse, evenly narrowed dorsally and emarginate in the middle (Fig. 2D), aedeagus simple, weakly curved dorsally, narrow, with elongate narrow and ventrally curved apical lamella, endophallus with three 
denticles at apex near lamella (Fig. 2F), tegmen long, narrow, with thin and short pointed parameres those are 2.3 times as short as the base of tegmen (Fig. 2G).

LeNGTH. $3.8 \mathrm{~mm}$, width (at elytral base) $0.8 \mathrm{~mm}$.

Female differs in having simple head and pronotum lacking sculpture, anterior tarsi simple, lacking a comb above the $2^{\text {nd }}$ tarsomere, antennae dentate with the $3^{\text {rd }}$ and $4^{\text {th }}$ antennomeres narrow-triangular, and of the equal shape and length, anterior tibiae lacking excavation, but with stretched outer edge bearing the $1^{\text {st }}$ tarsomere, anterior femora lacking tooth, metathorax evenly convex lacking appendages, inner side of the apex of anterior and intermediate tibiae with a row of setae similar to that in tarsal comb of male, abdomen long, with four segments extending beyond apex of the elytra.

LENGTH. $4.3 \mathrm{~mm}$, width (at elytral base) $1.0 \mathrm{~mm}$.
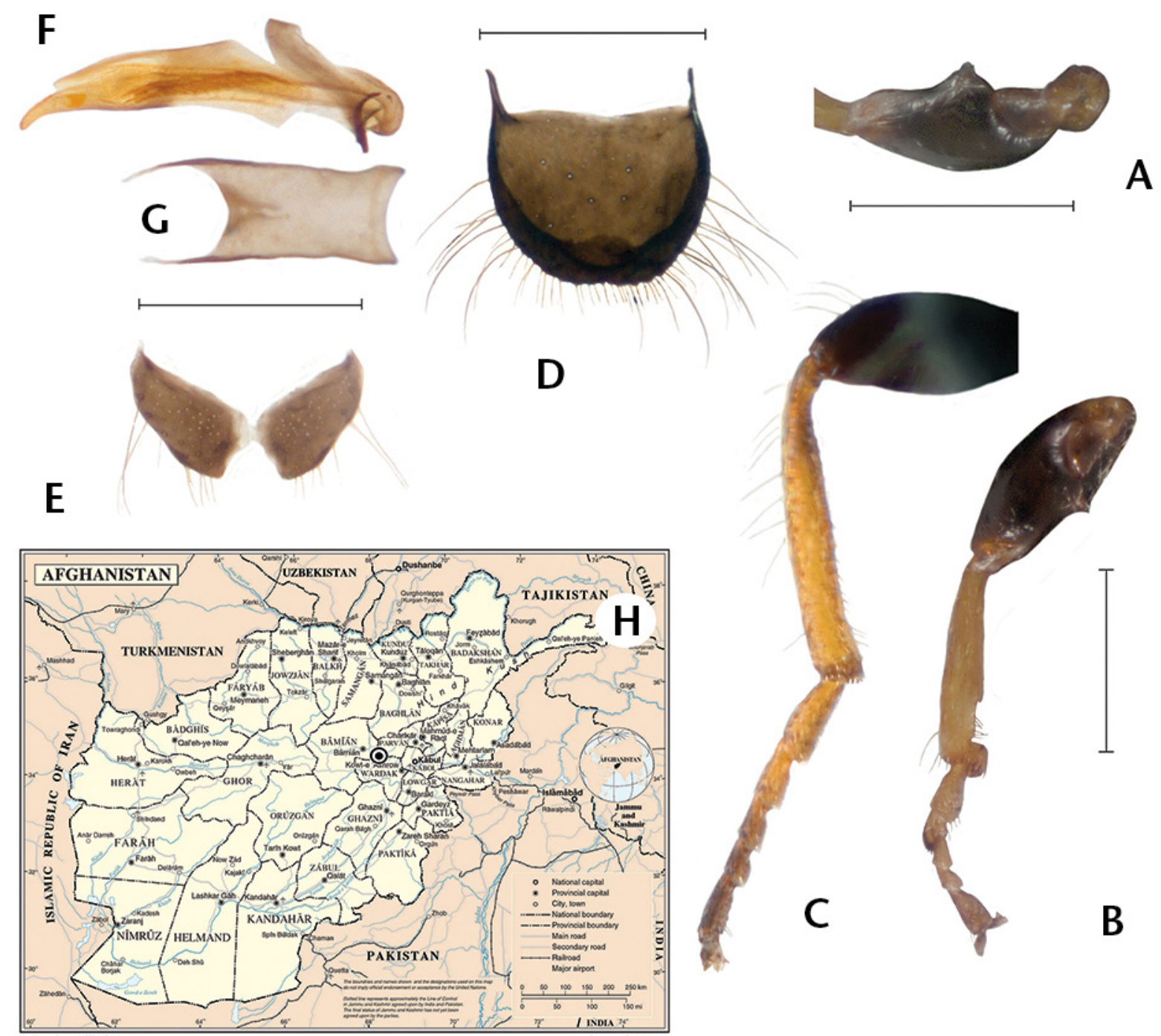

Fig. 2. Pectotibialis paghmanensis Tshernyshev gen. et sp. nov., holotype, đ̂. A. Femur of left anterior leg. B. Left anterior leg, ventral view. C. Left intermediate leg, ventral view. D. Pygidium. E. Ultimate abdominal ventrite. F. Aedeagus, dorsal view. G. Tegmen. H. Distribution map. Scale bars: $0.5 \mathrm{~mm}$. 


\section{Distribution}

Known from type locality only, Afghanistan: Paghman environs (Fig. 2H).

Key to the genera of the tribe Apalochrini with simple not modified $1^{\text {st }}, 3^{\text {rd }}$ and $4^{\text {th }}$ antennomeres

1. Male special structures are indistinct, antennae filiform or flabellate ...................................................2

- Male special structures distinct and located on head, antennae, pronotum, metathorax, sternites or legs

2. Second segment of anterior tarsi lacking a comb above, elytra with green or blue metallic lustre Apalochrus Erichson, 1840

- Second segment of anterior tarsi with a comb above, elytra entirely black, sometimes with metallic lustre

3. Body of staphylinoid shape, narrow, black, lacking metallic lustre, elytra strongly shortened and not covering abdomen, wings reduced, antennae filiform Paratinoides Medvedev, 1964

- Body typical of Malachiidae, elytra completely covering the abdomen .................................................

4. Anterior tibiae simple, not widened or impressed, antennae flabellate of filiform .................................5

- Anterior tibiae widened or impressed distally, antennae flabellate .........................................................

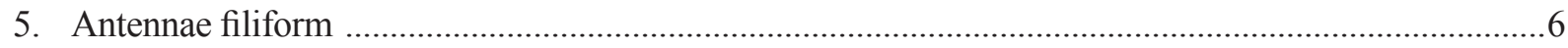

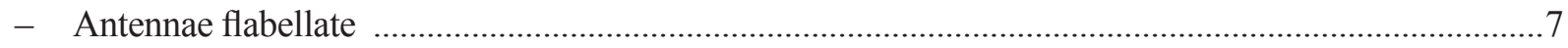

6. Antennomeres simple, not widened and slightly flattened, lacking impressions or grooves, anterior femora simple, lacking emarginations; surface of the body covered with long erect and short adpressed black pubescence

Protapalochrus Evers, 1987

- Intermediate $3^{\text {rd }}$ and $6^{\text {th }}$ antennomereswidened,dorsalsideof $5^{\text {th }}-10^{\text {th }}$ antennomeressulcateinmiddle, anterior femora with oval emargination in apical half covered with white pubescence; surface of the body covered with short semi-erect and adpressed black-brown pubescence .......Acroapalochrus Tshernyshev, 2020

7. Pronotum simple, lacking longitudinal grooves ...........................Pectapalochrus Tshernyshev, 2016

- Pronotum bisulcate in middle ......................................................................... Airomalachius Pic, 1950

9. Anterior tibiae compressed and widened in apical half, intermediate tibiae impressed and flattened in outer side with weakly widened and curved apices, pronotum convex and narrowly depressed at base, elytra and pronotum uniformly dark with green or blue metallic lustre and covered with long erect grey hairs

Mesapalochrus Tshernyshev, 2020

- Anterior tibiae slightly widened anteriorly and weakly impressed dorsally, intermediate tibiae simple, not widened and not flattened, pronotum convex, not depressed at base, orange with longitudinal greenbronze stripe in a middle, elytra orange-yellow, each with two bronze metallic oval-triangular spots, surface covered with short erect fine white pubescence

Nudopectinus Evers, 1987

10. Anterior tibiae simple, not widened or emarginate, male special structure is located in apical half of the pronotum as transverse fissure with elevate side and protuberance behind, anterior tarsi with a comb above the $2^{\text {nd }}$ tarsomere, posterior tibiae slightly but distinctly swollen in basal fourth

Simoderus Abeille de Perrin, 1891

- Anterior tibiae slightly but distinctly widened, simple or emarginate, pronotum simple or with protruding process in anterior side, male special structures located in femora or tibiae, head, metathorax or abdominal ventrites; anterior tarsi with a comb above $2^{\text {nd }}$ tarsomere or lacking it ...........................11

11. Anterior tibiae simple, not emarginate, anterior tarsi with a comb above $2^{\text {nd }}$ tarsomere ......................15

- Anterior tibiae emarginate at apical part, anterior tarsi with a comb above $2^{\text {nd }}$ tarsomere or lacking

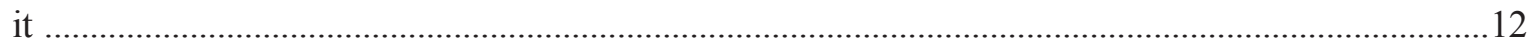

12. Head with emarginations and protuberances, antennae serrate or flabellate, abdomen simple ............13

- Head simple, lacking emarginations and protuberances, antennae filiform .........................................14

13. Pronotum with narrow horn-like process protruding over the head, antennae

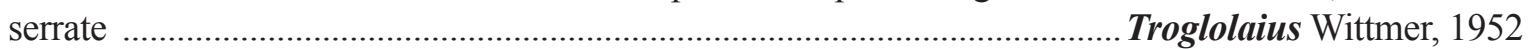

- Pronotum simple, antennae flabellate ...................................................... Trogloapalochrus Pic, 1919 
14. $4^{\text {th }}$ and $5^{\text {th }}$ abdominal ventrites modified and with thorn-like process in the middle ……………….....15

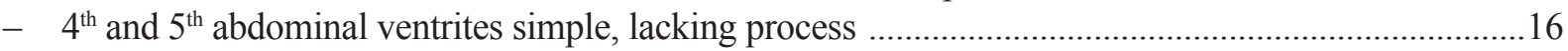

15. Intermediate tibiae slightly widened and swollen, with the inner side emarginate at apical quarter, trochanters of anterior legs simple ...................................................... Opisthapalochrus Evers, 1987

- Intermediate tibiae simple, not widened or emarginate, trochanters of anterior legs

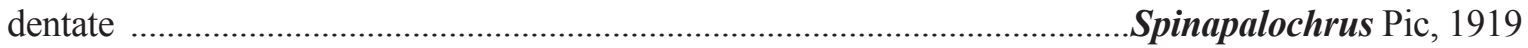

16. $2^{\text {nd }}$ tarsomere in anterior legs with a comb above ............................................................................17

- $2^{\text {nd }}$ tarsomere in anterior legs lacking a comb above, antennae serrate, anterior tibiae evenly emarginate, intermediate tibiae widened and narrowly emarginate, with pheromone glands ............................................................. Mesopezus Jacobson, 1911 (=Epitinus Evers, 1987)

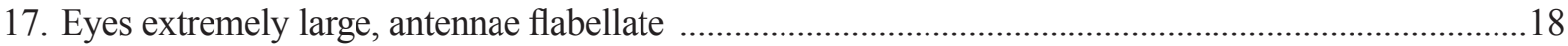

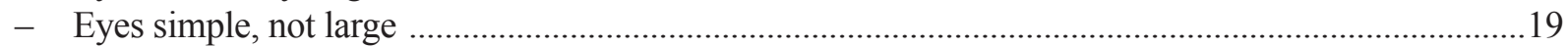

18. Metathorax swollen with appendage in the middle, elytral apices impressed near suture, anterior and intermediate femora swollen, intermediate tibia slightly widened posteriorly and possessing pheromone glands Mimapalochrus Tshernyshev, 2015

- Metathorax weakly swollen, lacking appendage in a middle, elytral apices not impressed, simple, all legs simple, not widened or curved, without glands ....................... Oculapalochrus Tshernyshev, 2015

19. Metathorax strongly swollen and possessing gladiate or rudimentary appendage with hairs in the

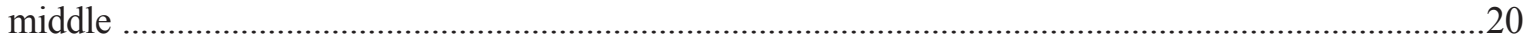

- Metathorax slightly swollen, lacking appendage or hairs ……………...........................................18

20. Anterior tibiae slightly emarginate, intermediate tibiae swollen with apical margin simple and lacking setae, pronotum and head simple, lacking relief sculpture, metathorax possesses gladiate appendage in the middle directed to intermediate coxae, elytra completely covering the abdomen ......................................................Dromanthomorphus Pic, 1921 (=Pectinus Evers, 1987)

- Anterior tibiae deeply emarginate in apical quarter, apical margin of anterior and intermediate legs surrounded with pectinate setae similar to that in tarsal comb; intermediate tibiae slightly widened, not stout, with longitudinal groove within, pronotum with protuberance in basal half, forehead bituberculate, metathorax slightly swollen and impressed in the middle with two appendages, one lamellate transverse above, and the other appendage longitudinal with vertical round semi-transparent lamellate apex below, elytra not covering two apical segments of the abdomen ................Pectotibialis Tshernyshev gen. nov.

21. Anterior tibiae strongly modified, deeply emarginated with lamellate processes, inner spurs of the anterior legs modified, antenna flabellate or filiform

- Anterior tibiae slightly widened or weakly emarginate, simple, spurs short and simple, antenna filiform

22. $1^{\text {st }}$ tarsomere in anterior legs enlarged and compressed, leaf-shaped, dorsally with a row of golden hairs forming a tuft, $2^{\text {nd }}$ tarsomere very short, almost completely covered by the vane-shape longitudinal comb, anterior tibiae strongly emarginate, with a stretched apex bearing enlarged hook-like spur, intermediate tibiae strongly widened and modified, emarginate within and possessing a row of long hairs inside the emargination, antennae flabellate

Hapalochrops Bourgeois, 1908

- $1^{\text {st }}$ tarsomere in anterior legs slightly enlarged and swollen, round-quadrate, $2^{\text {nd }}$ tarsomere with a simple short comb above, outer spur in anterior tibiae long and strong, thorn-like, intermediate tibiae with deep emargination in apical quarter, and a long narrow appendage bearing hair tuft in apex of inner side of the emargination, antennae filiform .....

Tibipectinus Tshernyshev, 2020

23. Anterior tibiae weakly widened distally, not emarginate, intermediate tibiae widened in apical half and sulcate in the middle of inner side, lacking emarginations

Protopectinus Tshernyshev, 2020

- Anterior tibiae weakly emarginate in dorsal or ventral side, intermediate tibiae stout and emarginate or thin and not emarginate

24. Anterior tibiae emarginate in dorsal side, intermediate tibiae strongly dilate and convex, with triangular perpendicular process in a middle of inner side and strongly emarginate beneath it .......

Hadrocnemus Kraatz, 1895 
- Anterior tibiae emarginate in ventral side, intermediate tibiae not widened and with a row of long erect thin hairs on inner side

Setapalochrus Evers, 1988

\section{Discussion}

38 genera are currently listed in the tribe Apalochrini worldwide, of which 23 genera, Acroapalochrus Tshernyshev, 2020, Airomalachius Pic, 1950, Apalochrus Erichson, 1840, Dromanthomorphus Pic, 1921 (= Pectinus Evers, 1987), Hadrocnemus Kraatz, 1895, Hapalochrops Bourgeois, 1908, Mesapalochrus Tshernyshev,2020, Mesopezus Jacobson, 1911 (=Epitinus Evers, 1987)(Tshernyshev, 2003), Mimapalochrus Tshernyshev, 2015, Nudopectinus Evers, 1987, Oculapalochrus Tshernyshev, 2015, Opisthapalochrus Evers, 1987, Paratinoides Medvedev, 1964, Pectapalochrus Tshernyshev, 2016, Pectotibialis Tshernyshev gen. nov., Protapalochrus Evers, 1987, Protopectinus Tshernyshev, 2020, Setapalochrus Evers, 1988, Simoderus Abeille de Perrin, 1891, Spinapalochrus Pic, 1919, Trogloapalochrus Pic, 1919, Troglolaius Wittmer, 1952 and Tibipectinus Tshernyshev, 2020, are belonging to the group "with simple not modified $1^{\text {st }}, 3^{\text {rd }}$ and $4^{\text {th }}$ antennomeres in male" and 15 genera, Collops Erichson, 1840, Dicranolaius Champion, 1921, Eulaius Wittmer, 1996, Flabellolaius Wittmer, 1952, Heterolaius Champion, 1920, Intybia Pascoe, 1866, Laius Guérin-Méneville, 1831 (= Nossibeus Evers, 1994), Myrmecospectra Motschulsky, 1858 (= Myrmecophasma Bourgeois, 1885), Notointybia Liu, Ślipiński \& Pang, 2020, Protocollops Evers, 1991, Stenolaius Wittmer, 1995, Syndesmolaius Evers, 1986, Zelotypus Abeille de Perrin, 1900, Troglocollops Wittmer, 1965 and Troglointybia Tshernyshev, 2015, belong to the group "with specific male structures located on $1^{\text {st }}, 3^{\text {rd }}$ and $/$ or $4^{\text {th }}$ antennomeres".

Representatives of the first group are typical residents of Eurasia, Indo-China, South East Asia, Australia and Africa with high species diversity in southern regions (Tshernyshev 2011, 2012a). Species of the second group are also occurring in these regions, but most diverse in Australia and also represented in American continent. Due to the absence of their fragments in fossil remains, the tribe Apalochrini can be considered as the youngest in the family Malachiidae, and, probably originated from the tribe Illopini, that is also similar to Malachiini due to the small size of the second antennomere. The wide species distribution, from Africa to Arctic region of Eurasia, allows a high evolutionary potential of the tribe in adaptation to different type of habitats to be assumed. The tribe is at present being actively studied, and the description of several new species from southern regions is to be expected in the nearest future. The present generic revision can help in the understanding of the taxonomic diversity of the family Malachiidae and the remarkable tribe Apalochrini.

\section{Acknowledgments}

The author is grateful to Dr Roman Yakovlev (Barnaul State University, Russia) for his help in obtaining the Malachiidae, to Mr Oleg Pak (Donetsk, Ukraine) for collecting soft-winged flower beetles in Afghanistan, to Isidor Plonski (Vienna, Austria) for help regarding literature sources and discussion of Malachiidae taxonomy, and to Prof. Mark Seaward (Bradford University, UK.) for advice and linguistic revision of the text. This study was supported by the Russian Foundation for Basic Research (grant no. 19-04-00465-a), as well as the Program of Basic Scientific Research (FNI) of the State Academies of Sciences, project no. 0247-2021-0004.

\section{References}

Asano M. 2013a. Early instar larvae of Intybia niponicus (Lewis) (Coleoptera, Malachiidae) and comparison with a clerid lst instar: the foetomorphic larva in Malachiidae, II. Japanese Journal of Systematic Entomology 19 (1): 21-27.

Asano M. 2013b. New combinations and redescriptions of six species of the tribe Ebaeini Portevin (Coleoptera, Malachiidae) in Japan. Japanese Journal of Systematic Entomology 19 (2): 275-284. 
Asano M. 2015. Taxonomic notes on some Malachiid beetles of Taiwan, with description of a new species of the genus Intybia Pascoe (Coleoptera: Malachiidae). Japanese Journal of Systematic Entomology 21 (1): 77-82.

AsanoM.2017.MorphologyandbiologyofMalachiusprolongatus(Coleoptera:Melyridae:Malachiinae). Acta Entomologica Musei Nationalis Pragae 57 (2): 603-615.https://doi.org/10.1515/aemnp-2017-0092

Asano M. 2018. Taxonomy and biology of the genus Attalus Erichson of Japan with description of the new species (Coleoptera: Melyridae). Japanese Journal of Systematic Entomology 24 (1): 55-66.

Asano M. \& Kawashima I. 2010. Discovery of the genus Dicranolaius (Coleoptera, Malachiidae) from Japan with description of a new species. Japanese Journal of Systematic Entomology 16 (2): 261-266.

Asano M. \& Kojima H. 2009. On the mature larvae of the genus Laius (Coleoptera, Malachiidae) from Japan. Japanese Journal of Systematic Entomology 15 (2): 481-486.

Asano M. \& Kojima H. 2013. Description of the early instars of Laius asahinai Nakane (Coleoptera: Malachiidae): first discovery of a foetomorphic larva in Malachiidae. The Coleopterists Bulletin 67 (1): 40-45. https://doi.org/10.1649/072.067.0109

Asano M. \& Kojima H. 2014. Occurrence of the genus Hypomixis Wittmer, 1995 in Japan (Coleoptera: Malachiidae). Japanese Journal of Systematic Entomology 20 (2): 301-303.

Asano M. \& Okajima Sh. 2013. First record of the genus Dromanthomorphus (Coleoptera, Malachiidae) from Laos, with notes on the sexual dimorphism. Japanese Journal of Systematic Entomology 19 (2): 257-260.

Asano M. \& Yoshitomi H. 2011. The larva of Carphurus pengaronae Champion (Coleoptera, Malachiidae, Carphurinae). Japanese Journal of Systematic Entomology 17 (2): 225-229.

Asano M., Kawashima I. \& Satou F. 2011a. Taxonomic status of Malachius okinawaensis Nakane (Coleoptera, Malachiidae ), with description of the male. Japanese Journal of Systematic Entomology 17 (2): 219-224.

Asano M., Kojima H. \& Okajima Sh. 2011b. The Malachiid-Beetles (Coleoptera) collected at rice paddies and its surroundings in Laos. Japanese Journal of Systematic Entomology 17 (2): 405-408.

Asano M., Ikeda H., Kamezawa H. \& Nomura Sh. 2018. Revision of six species of the subtribe Ebaeina of Japan, with description of a new species (Coleoptera: Melyridae). Japanese Journal of Systematic Entomology 24 (1): 141-149.

Constantin R. 2015. Le genre Laius Guerin-Meneville, 1830 dans l'Ocean Indien occidental, avec la description de quatre especes nouvelles (Coleoptera: Malachiidae). Contribution à l'étude des coléoptères de La Réunion: et des archipels de l'Océan Indien occidental 1: 78-85.

Geiser M. 2011. Nomenclatural note on Opistapalochrus Evers, 1987 (Coleoptera, Cleroidea, Malachiidae). Japanese Journal of Systematic Entomology 17 (2): 402-404.

LiuZ., ŚlipińskiA. \& Pang H. 2015. Notes on Australian Laius Guerin-Meneville, Dicranolaius Champion and Intybia Pascoe with description of new species related to Dicranolaius c-purpureus (Lea)(Coleoptera: Melyridae: Malachiinae). Zootaxa 3936 (2): 272-280. https://doi.org/10.11646/zootaxa.3936.2.7

Liu Z., Ślipiński A. \& Pang H. 2016. Contribution to the knowledge of the Australian Dicranolaius Champion (Coleoptera: Melyridae: Malachiinae). Annales Zoologici 66 (1): 101-112.

https://doi.org/10.3161/00034541ANZ2016.66.1.007

Liu Z., Ślipiński A. \& Pang H. 2017. Revision of the soft-winged flower beetle genus Dicranolaius Champion, 1921 (Coleoptera: Melyridae: Malachiinae) from Australia. Annales Zoologici (Warszawa) 67 (3): 405-548. https://doi.org/10.3161/00034541ANZ2017.67.3.001 
Mayor A.J. 2003. Nomenclatorial corrections for Dasytidae and Malachiidae (Coleoptera). Insecta Mundi 17 (1-2): 85-96.

Mayor A.J. 2007. Family Malachiidae Fleming, 1821, pp. 415-454. In: Löbl I, Smetana A. eds. Catalogue of Palaearctic Coleoptera, Volume 4. Elateroidea, Derontoidea, Bostrichoidea, Lymexyloidea, Cleroidea, Cucujoidea. Apollo Books, Stenstrup: 935.

Plonski I.S. 2013. Studies on the genus Intybia Pascoe (Coleoptera: Malachiidae) I. Some nomenclatorial acts and faunistic records. Zeitschrift der Arbeitsgemeinschaft Österreichischer Entomologen 65: 6168 .

Plonski I.S. 2014a. Studies on the genus Intybia Pascoe, part II. Faunistic and taxonomic notes, with description of a new species of the I. plagiata-group (Coleoptera: Malachiidae). Koleopterologische Rundschau 84: 313-320.

Plonski I.S. 2014b. Studies on the genus Intybia Pascoe (Coleoptera: Malachiidae) IV. Notes on the fauna of the Philippines. Zeitschrift der Arbeitsgemeinschaft Österreichischer Entomologen 66: 39-45.

Plonski I.S. 2015. Studies on the genus Stenolaius Wittmer (Coleoptera: Malachiidae) I. Faunistic and ecological notes on known species. Zeitschrift der Arbeitsgemeinschaft Österreichischer Entomologen 67: 39-43.

Plonski I.S. 2016. Studies on the genus Intybia Pascoe, 1866 (Coleoptera: Malachiidae) V. Contribution to internal classification and taxonomy, with faunistic and nomenclatorial notes. Zeitschrift der Arbeitsgemeinschaft Österreichischer Entomologen 68: 17-38.

Plonski I.S. 2017. Colotrema socotrana sp. nov. from Socotra Island, with new records of the genus from Yemen (Coleoptera: Malachiidae). Acta Entomologica Musei Nationalis Pragae (supplementum) 57: 125-131.https://doi.org/10.1515/aemnp-2017-0113

Plonski I.S. \& Geiser M. 2014. Studies on the genus Intybia Pascoe (Coleoptera: Malachiidae) III. On Intybia rubrithorax (Pic) and related taxa. Zeitschrift der Arbeitsgemeinschaft Osterreichischer Entomologen 66: 31-38.

Plonski I.S. \& Michael F. 2014. Geiser studies on the genus Intybia Pascoe (Coleoptera: Malachiidae) III. On Intybia rubrithorax (Pic) and related taxa. Zeitschrift der Arbeitsgemeinschaft Österreichischer Entomologen 66: 31-38.

Plonski I.S. \& Puchner A. 2014. Description of Laius alfredpuchneri sp. n. (Coleoptera: Malachiidae) from Thailand. Zeitschrift der Arbeitsgemeinschaft Österreichischer Entomologen 66: 47-50.

Tshernyshev S.E. 2003. Epitinus Evers, 1987 a junior synonym of Mesopezus Jacobson, 1911 (Coleoptera, Malachiidae). Euroasian Entomological Journal 2 (1): 61-62. [In Russian with English abstract.

Tshernyshev S.E. 2009. Anthomalachius, a new genus of soft-winged flower beetles (Coleoptera, Malachiidae). Zootaxa 1651: 65-68. https://doi.org/10.11646/zootaxa.2094.1.3

Tshernyshev S.E. 2011. A review of soft-winged flower beetles (Coleoptera, Malachiidae) of the fauna of Russia and the adjacent territories. 5. Keys to supraspecific taxa. Euroasian Entomological Journal 10 (3): 341-348. Colour plate V. [In Russian, with English abstract].

Tshernyshev S.E. 2012a. A review of soft-winged flower beetle fauna (Coleoptera, Malachiidae) of North Asia. Euroasian Entomological Journal 11 (6): 575-587. [In Russian with English abstract].

Tshernyshev S.E. 2012b. Two new species of soft-winged flower beetles of the genus Kuatunia Evers, 1945-48 (Coleoptera, Malachiidae) from China and northeastern Russia. Zootaxa 3191: 56-64. https://doi.org/10.11646/zootaxa.3191.1.5 
Tshernyshev S.E. 2015a. A new species of soft-winged flower beetles of the genus Platyebaeus Wittmer, 1995 (Coleoptera, Cleroidea, Malachiidae) from the Philippines. Zootaxa 3941 (2): 289-293. https://doi.org/10.11646/zootaxa.3941.2.9

Tshernyshev S.E. 2015b. A new species of soft-winged flower beetles of the genus Kuatunia Evers, 1945-48 (Coleoptera, Cleroidea, Malachiidae) from Nepal. Zootaxa 3941 (2): 255-260. https://doi.org/10.11646/zootaxa.3941.2.6

Tshernyshev S.E. 2015c. A review of species of the genus Apalochrus Erichson(Coleoptera, Malachiidae). Zootaxa 3941 (3): 358-374. https://doi.org/10.11646/zootaxa.3941.3.3

Tshernyshev S.E. 2015d. Taxonomic problems in the genus Sceloattalus Wittmer, 1966 (Coleoptera, Malachiidae). In: Hartmann M. \& Weipert J. (eds) Biodiversitat und Naturasstattung im Himalaya, volume 5. Erfurt: Verein der Freunde \& Förderer des Naturkundemuseums Erfurt e.V: 381-387.

Tshernyshev S.E. 2015e. Soft-winged flower beetles (Coleoptera, Malachiidae) of the Himalayan region, with notes on Apalochrini. In: Hartmann M. \& Weipert J. (eds) Biodiversitat und Naturasstattung im Himalaya, volume 5. Erfurt: Verein der Freunde \& Förderer des Naturkundemuseums Erfurt e.V: 389-405.

Tshernyshev S.E. 2016a. Pectapalochrus gen. nov., a new genus of soft-winged flower beetles of the tribe Apalochrini (Coleoptera, Malachiidae). Zoologicheskii zhurnal 95 (3): 300-305.

https://doi.org/10.7868/S0044513416030041 [In Russian with English abstract].

Tshernyshev S.E. 2016b. A review of species of the genera Protapalochrus Erichson and Paratinoides L. Medvedev (Coleoptera, Malachiidae). Zootaxa 4139 (3): 369-390.

https://doi.org/10.11646/zootaxa.4139.3.3

Tshernyshev S.E. 2016c. The genus Dromanthomorphus Pic, 1921 (Coleoptera, Cleroidea: Malachiidae) in South-East Asia. Zootaxa 4139 (4): 551-565. https://doi.org/10.11646/zootaxa.4139.4.7

Tshernyshev S.E. 2016d. Taxonomic revision of Intybia Pascoe, 1886 species (Coleoptera, Malachiidae) of Thailand and Philippines. Zootaxa 4147 (2): 101-123. https://doi.org/10.11646/zootaxa.4147.2.1

Tshernyshev S.E. 2016e. New taxa of soft-winged flower beetles (Coleoptera, Malachiidae) in Baltic and Rovno amber. Paleontological Journal 50 (9): 953-962. http://doi.org/10.1134/S0031030116090021

Tshernyshev S.E. 2018. Himalacolotes, a new genus of soft-winged flower beetles of the tribe Colotini (Coleoptera, Malachiidae) from the Himalayan Region. In: Hartmann M., Barclay M. \& Weipert J. (eds) Biodiversitat und Naturasstattung im Himalaya, volume 6. Erfurt: Verein der Freunde \& Förderer des Naturkundemuseums Erfurt e.V: 455-489.

Tshernyshev S.E. 2020a. Acroapalochrus gen.n. - a new genus of soft-winged flower beetles (Coleoptera, Malachiidae) from West Africa. Journal of Insect Biodiversity 14 (1): 1-5.

https://doi.org/10.12976/jib/2020.14.1.1

Tshernyshev S.E. 2020b. Protopectinus pseudoparatinus - a new species and a new genus of softwinged flower beetle of the tribe Apalochrini (Coleoptera: Malachiidae) from East Africa. Russian Entomological Journal 29 (1): 69-72.

Tshernyshev S.E. 2020c. Mesapalochrus gen. nov. - a new species and a new genus of soft winged flower beetle of the tribe Apalochrini (Coleoptera: Malachiidae) from Africa. Invertebrate Zoology 17 (2): 195-201. https://doi.org/10.15298/invertzool.17.2.09

Tshernyshev S. \& Kopetz A. 2018. Myrmecospectra Motschulsky, 1858 - the real name for Myrmecophasma Bourgeois, 1885 (Coleoptera, Cleroidea, Malachiidae), with review of species and description of a new species from the Himalayas. In: Hartmann M., Barclay M. \& Weipert J. (eds) Biodiversitat und Naturasstattung im Himalaya, volume 6. Erfurt: Verein der Freunde \& Förderer des Naturkundemuseums Erfurt e.V: 443-453. 
Tshernyshev S.E. \& Shcherbakov M.V. 2020. A new genus and species of soft winged flower beetle of the tribe Apalochrini (Coleoptera: Malachiidae) from Africa. Far Eastern Entomologist 416: 1-9. https://doi.org/10.25221/fee.416.1

Yoshitomi H. 2008. Contribution to the taxonomy of the genus Laius Guerin-Meneville in Indonesia, with description of a new species (Coleoptera: Malachiidae). Koleopterologische Rundschau 78: 285-290.

Yoshitomi H. 2010. A new species of the genus Laius (Coleoptera, Malachiidae) from Mauritius. Japanese Journal of Systematic Entomology 16 (1): 1-4.

Yoshitomi H. 2014. Comparative morphology of the endophallic structures of the genus Laius (Coleoptera, Melyridae), with the descriptions of three new species. European Journal of Taxonomy 97: 1-29. https://doi.org/10.5852/ejt.2014.97

Yoshitomi H., Ahn K.J. \& Ogawa N. 2015. Some new distributional records of the genus Laius (Coleoptera, Melyridae). Elytra, New Series 5 (1): 115-119.

Yoshitomi H. \& Lee Ch.F. 2010. Revision of the Taiwanese and Japanese species of the genus Laius (Insecta: Coleoptera: Malachiidae). Zoological Studies 49 (4): 534-543.

Manuscript received: 2 March 2021

Manuscript accepted: 2 September 2021

Published on: 14 October 2021

Section editor: Max Barclay

Topic editor: Nesrine Akkari

Desk editor: Fariza Sissi

Printed versions of all papers are also deposited in the libraries of the institutes that are members of the EJT consortium: Muséum national d'histoire naturelle, Paris, France; Meise Botanic Garden, Belgium; Royal Museum for Central Africa, Tervuren, Belgium; Royal Belgian Institute of Natural Sciences, Brussels, Belgium; Natural History Museum of Denmark, Copenhagen, Denmark; Naturalis Biodiversity Center, Leiden, the Netherlands; Museo Nacional de Ciencias Naturales-CSIC, Madrid, Spain; Real Jardín Botánico de Madrid CSIC, Spain; Zoological Research Museum Alexander Koenig, Bonn, Germany; National Museum, Prague, Czech Republic. 